\title{
Sustainability assessment of a slum upgrading intervention in Bangladesh
}

\author{
Isoline Degert, Priti Parikh*, Rumana Kabir \\ Sciences Po Paris, University College London, Abashon Ltd.UK.
}

\begin{abstract}
Equitable provision of physical infrastructure must be seen as a prerequisite for achieving the sustainability of human settlements. Infrastructure provision needs to consider both the product (physical services) and the context in which the services will be provided and maintained in order to be sustainable. This article presents a holistic methodology for evaluating sustainability and poverty reduction impact of infrastructure projects in developing countries through societal, economics, institutional and environmental dimensions. ASPIRE toolkit uses qualitative evidence which feeds into 96 indicators producing visual outputs which can encourage users to consider contextual issues and develop valuable trade-offs between the four dimensions.

The methodology and toolkit is applied to the evaluation of an infrastructure upgrading project in Korail, Bangladesh. The Urban Partnership for Poverty Reduction Project (UPPRP) in Korail, supports a twin-pronged approach of provision of infrastructure (water, sanitation, roads and drainage) improvement through the Slum Improvement Fund and improvement of socio-economic conditions through the Socio-Economic Funds. The ASPIRE assessment allowed the authors to interrogate strengths and weaknesses of the UPPR project thereby demonstrating the value added by ASPIRE. Overall, the project was deemed successful in Korail. Socially, it allowed access to all types of services to the slum's residents with strong community engagement. Land security however was noted to be a challenge, which needs to be addressed by institutions in Dhaka.
\end{abstract}

Keywords: Sustainability, ASPIRE, infrastructure, slums, Bangladesh, poverty 


\section{Introduction}

With high rates of population growth and urbanisation it is crucial to ensure that cities grow sustainably with equitable access to basic services (Parikh, Fu, Parikh, McRobie and George, 2015). The proliferation of slums in major urban centres in developing countries reflects a failure of mainstream development strategies to accommodate urbanisation and population growth in cities. The global population will increase by 2 billion by 2030, with most of the increase occurring in the developing world, and predominantly in urban informal settlements (Bhattacharya, Romani and Stern, 2012).

Currently 2.5 billion people lack access to sanitation, 1.8 billion people use a source of drinking-water that is contaminated and 1.3 billion people lack electricity to light their homes (Sustainable Energy for All, 2013; WHO/UN-Water, 2014). The infrastructure gap is predominant in developing countries in settings such as slums which comprise of limited resources. The provision of infrastructure which is sustainable and equitable has the potential to reduce poverty and improve living conditions (Jahan and McCleery, 2005, Parikh, Parikh and McRobie, 2012). Equitable provision of physical infrastructure must be seen as a prerequisite for achieving the sustainability of human settlements and thereby enabling future cities to maintain a balance with their environment (Choguill, 1996). A different approach is required to ensure that infrastructure developments are sustainable and contribute to reducing poverty. This requires consideration of both the product (water supply, road etc) and the process by which it is conceived, implemented and operated based on criteria which determine project success in terms of outcomes rather than outputs (Arup and Engineers Against Poverty (EAP), 2009). In practice, developing infrastructure that supports poverty reduction and well being through sustainable processes requires tools that support the integration of these core characteristics in to the project throughout the entire infrastructure project life cycle, and help those funding, commissioning, designing and implementing infrastructure projects to consider a wider range of issues and stakeholder concerns (Arup and EAP, 2009).

This article demonstrates the use of ASPIRE toolkit to assesses the sustainability of the UPPR project for Dhaka city in Korail which is the largest slum settlement in Bangladesh. The UPPR initiative seeks to enhance the livelihoods and living conditions of at least three million poor people within informal settlements. Throughout its duration, the project supports settlement infrastructure improvement, socio-economic development, community mobilisation, education, local government capacity building and pro-poor policy advocacy (UN-HABITAT, 2014).

\section{The conceptual framework}

For the developing country context, poverty alleviation combined with equitable distribution of resources and access to basic services is crucial to develop sustainable cities. A review of 57 different tools (Nielson, 2010) highlights a strong focus on economics and/or environmental concerns with limited attention paid to complex social and community challenges such as social equity, capacity building and human development. A comparative assessment of toolkits (Arup and EAP, 2009) highlighted that there was a gap in relation to frameworks which addressed both poverty reduction and sustainability effectively through different stages of project life cycle and was 
directly applicable to infrastructure projects in developing countries. In response to this gap, the ASPIRE assessment tool was developed and launched by Arup and EAP.

ASPIRE's conceptual framework acknowledges that the planet has limited resources and a limited capacity to support an ever increasing population that seeks for a higher quality of life. The resulting conflict between societal needs and environmental impacts encourages needs to be balanced at both local and global level to achieve sustainable development. The enablers of strong international structures and processes (Figure 1) along with well-proportioned economic development play a critical role in brokering the interplay between environmental resources and societal consumption (Arup and EAP, 2009).
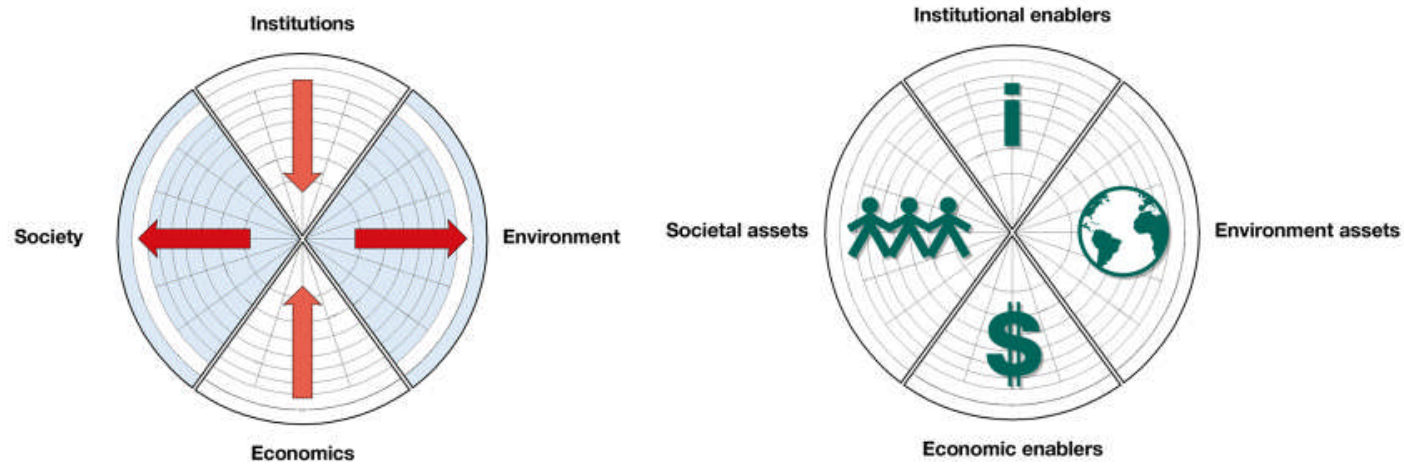

Figure 1: ASPIRE Conceptual Framework (Source: Arup and EAP, 2009)

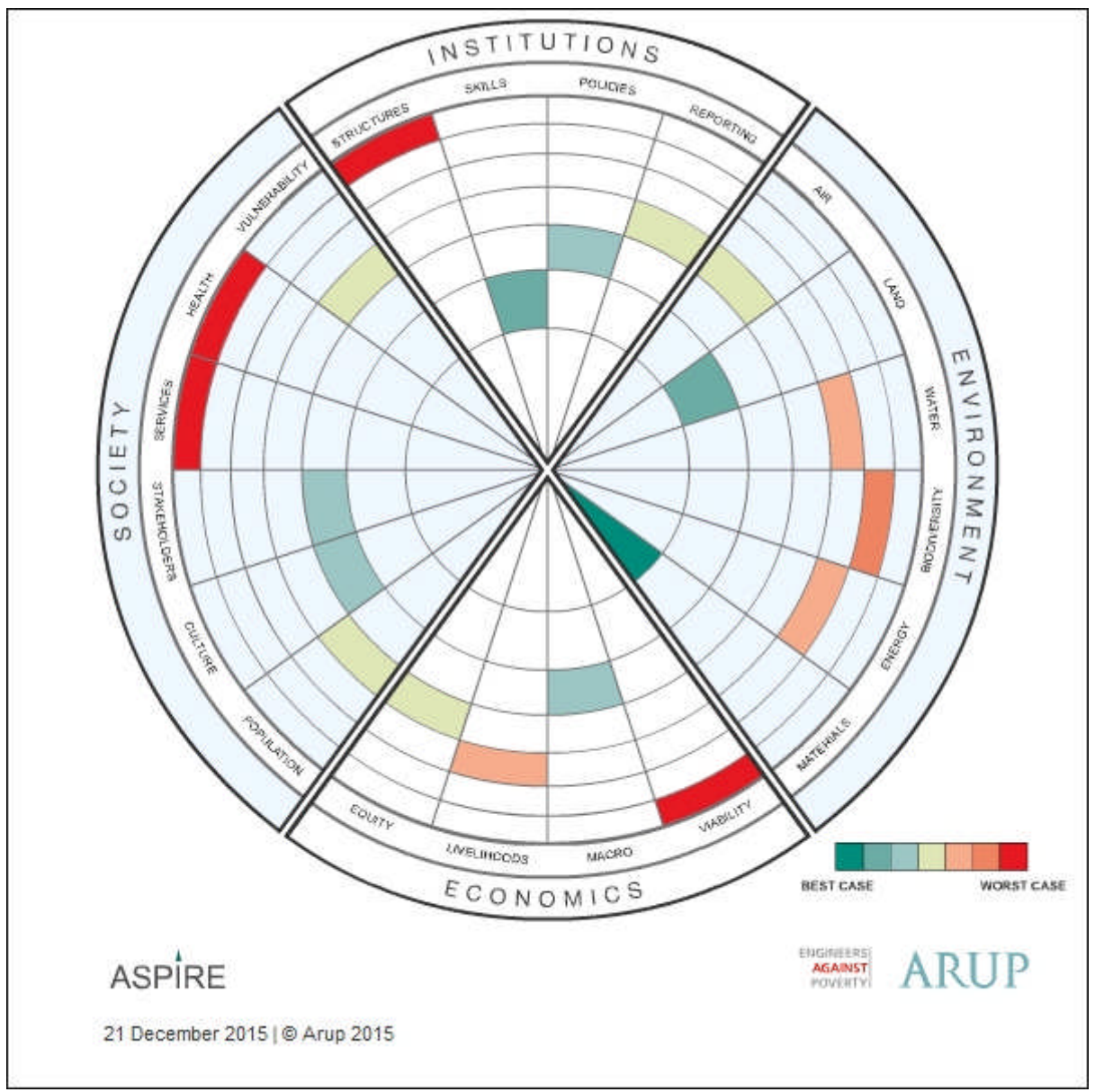

Figure 2: ASPIRE Visual Output for Illustrative purposes. 
The ASPIRE conceptual framework uniquely has four dimensions: society, environment, economic and institutions. These are presented as inter-locking keystones forming a circle in recognition of their dependence on one another (see Figure 2). The inclusion of the institutional enabler was a key finding of the comparative analysis of assessment frameworks and mirrors the four core dimensions of social, environmental, economic and institutional used by the United Nations Commission on Sustainable Development (CSD). The four dimensions of ASPIRE also reflect the DFID Sustainable Livelihoods approach assuming that the fifth dimension of physical assets is the project itself (Arup and EAP, 2009).

Each keystone within ASPIRE respresents a theme or heading which is constructed of multiple indicators (sub-themes), The software's interface guides the users through a series of questions for each sub-theme and aggregate scores for each theme. The user interface also provides guidance on the best and worst case scenario for each indicator so that users can make a judgement of how their project would sit between the best and worst case scenario for each indicator. The scores are represented visually through a traffic light system where dark red and dark green represents worst and best performance on projects based on the scenario guidance and user scores. The visual output not only provides strength and weakness of the project but also enables users to make trade-offs between societal improvements, economic considerations, institutional capacity and environmental factors.

\section{Case Study}

\section{Bangladesh}

Bangladesh's capital city of Dhaka is the fastest growing megacity in the world with an estimated population of 12 million out of $28 \%$ live in poverty (World Bank, 2013). The rapid growth of Bangladesh with about 500,000 migrants (Cities Alliance, 2014) every year has resulted in Dhaka city now housing 3.4 million slum dwellers, the third largest population in the world after Mexico and Mumbai (World Bank, 2013; Davies, 2007). Coupled with the population increase, the rising threats of climate change and a poverty rate above 20\% (Bangladesh Bureau of Statistics (BBS), 2010) planning truly sustainable urbanisation becomes a pressing need as it encompasses a solution that holds the potential to minimise both environmental and social threats.

The Urban Partnerships for Poverty Reduction Project (UPPRP) built on the experience of an earlier United Nations Development Project (UNDP) project, the Local Partnerships for Urban Poverty Alleviation Project (LPUPAP, 2000-2007) (UNHABITAT, 2014). Building on the previously successful LPUPAP initiative, UPPRP was then set up in 2008 with the ambition of lifting residents out of poverty through a community based approach (UPPR, 2013). Given the multi-dimensional nature of poverty UPPRP set up two distinct funding streams to provide holistic inputs. The first funding stream titled the Settlement Improvement Fund (SIF) provided direct financial support for the provision of physical infrastructure in slums (UPPR, 2013). The second funding stream title Socio-Economic Fund (SEF) provided funds for livelihood creation, access to training and education for children (UPPR, 2013). 
An evaluation of the project in 2014 through sample evidence captured from 2479 settlements in Bangladesh noted significant improvement in the provision of water, sanitation and infrastructure as compared to the year of 2010. From 2008 to 2014, the project has financed circa 5334 contracts for provision of physical services such was latrines, water points, improved access and drains (UPPR, 2015). Within the 23 towns where community development committees were set up, around $51 \%$ if settlements reported significant improvement in water and sanitation infrastructure conditions (UPPR, 2015). Around 85\% of women who were supported through SEF in 2012/13 were still operating their businesses in 2014. The Government of Bangladesh is now reformulating the UPPRP into the National Urban Poverty Reduction Programme (NUPRP) which has the ambition to reach 9 million citizens (UPPR, 2015).

\section{Korail}

The authors use one of the largest slums in Bangladesh, Korail as their case study. Located on 90 acres of land and owned by three governmental agencies Korail developed through an influx of migrants in the 1990's. Korail slum (basti) now comprises of more than 20000 families which are located adjacent to Gulshan Lake (DSK, 2012). The houses made of corrugated iron often offer a single room where five or six family members live crowded together. Residents are engaged in a multitude of livelihood activities ranging from working in garment factories, rickshaw drivers, vendors and scavengers for solid waste thereby serving the more affluent neighbourhoods and also the surrounding commercial and mixed used industrial estates (ICDDRB, 2009).

Korail is faced with poor environmental conditions. As the slum is sited on low-lying land and is encircled with Gulshan Lake's water, a large number of families live in houses that are often prone to waterlogging and flooding further aggravated during monsoon. The density of airborne particulate matter is more than 20 times the recommended level in Dhaka which would have a negative impact on residents (Integrated Regional Information Network (IRIN), 2009). The City Corporation of Dhaka only collects half of the solid waste generated within the municipality with the uncollected waste dumped either in water bodies and floodplains or burnt, which causes water, land and air pollution of the city area (Matter, Dietschi and Zurbrügg, 2013). Solid waste management systems are rendered ineffective in slums with narrow access routes and lack of adequate infrastructure. The environment in which people live makes it too often unrealistic to search for a better quality of life. Ghafur's (2000) explores the role of social factors in forming households' claims on urban interventions in Bangladesh. He discusses key institutional constraints imposed by the local government on services to the poor households.

Ahmed and Ali (2006) discuss the failure of the public sector to respond to the increased demand for waste services as it is constrained by resources and institutional limitations. They call for a multileveled participation of the public sector, the private sector and citizens - a tripartite partnership - to facilitate solid waste management service delivery in Bangladesh (Ahmed and Ali, 2006). Delwar, Minnery, Van Horen and Smith (2007) present an innovative model for community and institutional supply of potable water to the urban poor in Dhaka. The model identifies reasonable ways of providing small-scale water supplies for slums and also explains how the urban poor could facilitate their provision of basic services (Delwar et al, 2007). 
Similarly, Frota (2008) discusses the difficulty to accommodate the urban poor residing in slums or other informal settlement in rapidly urbanising cities such as Dhaka. He proposes an integration of economic promotion policies with social protection instruments' public policies. These could mitigate the effects of social risks on poverty but could also create conditions to allow people to work out of poverty. As is the case in this research, Frota exposes the challenge of breaking down the conceptual and administrative barriers that inherently oppose economic development and social protection. That dissolution would result in reducing the costs of access to productive and basic social services such as health care or social safety nets and would also remove obstacles to local development in urban areas (Frota, 2008).

In Bangladesh, the urban governance system is much influenced by a highly politicised bureaucracy that operates through a network of politicians and bureaucrats working together to satisfy mutual benefits. In any way, socio-economic disparity within cities associated with ineffective governance and entrenched corruption, makes the planning of urban governance even more complex (Khan and Swapan, 2013).With Dhaka's local government refusing to acknowledge the city's spreading slums and their inhabitants and dwellers lacking legal representative's threats of evictions are deemed routine challenges for slum residents. More than 2000 houses were demolished in Korail as part of a major slum eviction drive (Subramanian and May 2012). A range of approaches ranging from eviction to resettlement have been tried and tested in Bangladesh in the last thirty years (Mohit, 2012). Ad hoc land tenure policies are one of the contributing factors to a growing fear of eviction within the residents of slums.

Rahman (2002) discusses the significant role of NGOs in supplementing the Bangladeshi government efforts for socio-economic and environmental development programs. However, Smets (2006) presents incremental building and financing strategies that are characterised by small amounts and short term time frames and also discusses the challenge of "thinking small" in practice. Access to financial structures is very limited for slum dwellers. The combination of lack of clarity with regards to land tenure and informal employment opportunities results in limited opportunities for investment in infrastructure and housing stock in slums in Dhaka. Past projects in the country provided short-term results but due to a lack of funds for operation and maintenance of the services brought, things quickly got back to the way they were prior to the initiatives.

\section{Methodology}

\section{ASPIRE Framework}

ASPIRE offers a holistic approach framework that takes into account environmental, societal, economical and institutional imperatives. ASPIRE's conceptual framework acknowledges that the planet has limited resources and a limited capacity to support an ever increasing population that seeks for a higher quality of life. This is valid for the context of Korail where residents lack access to basic services and are reliant on the ecosystem. Together with the fundamental enablers of strong international structures and processes along with well-proportioned economic development, the built environment plays an essential role in brokering that relationship (Arup \& EAP, 2009). 
ASPIRE includes four interconnected dimensions within which, distinctive 20 themes are identified (Arup \& EAP (b), 2009):

- Environment comprising of six themes: air, land, water, biodiversity, materials and energy (recognises the importance of renewable energy and energy efficiency);

- Society considered in terms of four themes that represent the required assets to meet needs in a equitable way, promote human potential and reduce poverty through: access to services, public health, culture and stakeholder participation. Vulnerability and population are the two other themes and contain issues such as exposure to natural hazards, conflict and displacement;

- Economics incorporates four themes that contribute to the economic viability of the project: long-term viability, macro-economic effects, livelihood opportunity and equity of economic opportunity;

- Institutions includes four themes that consider both the effectiveness and capacity of the institutional context to support the delivery of infrastructures that help sustainable development: policy, governance, skills and reporting.

For each of the 20 themes indicators have been developed as shown in Table 1.

\begin{tabular}{|c|c|c|c|c|c|c|}
\hline \multirow[b]{2}{*}{$\begin{array}{l}\text { E } \\
\text { n } \\
\text { vi } \\
\text { ro } \\
\text { n } \\
\text { m } \\
\text { e } \\
\text { nt }\end{array}$} & Air & Land & Water & Biodiversity & Energy & Materials \\
\hline & $\begin{array}{l}\text { Air quality } \\
\text { Direct emissions } \\
\text { Dust \& particulates } \\
\text { Ozone depleters } \\
\text { Indirect emissions }\end{array}$ & \begin{tabular}{|l|} 
Site location \\
Planning intent \\
Diversity/ \\
Mixed use \\
Contaminated land \\
Soil conservation
\end{tabular} & $\begin{array}{l}\text { Drainage systems } \\
\text { Water pollution } \\
\text { Sewage treatment } \\
\text { \& disposal } \\
\text { Water availability } \\
\text { Water efficiency }\end{array}$ & $\begin{array}{l}\text { Protected area } \\
\text { Nature } \\
\text { conservation } \\
\text { Aquatic } \\
\text { ecosystems } \\
\text { Forests } \\
\text { Drylands } \\
\text { Environment risk } \\
\text { management } \\
\end{array}$ & $\begin{array}{l}\text { Energy } \\
\text { efficiency } \\
\text { Energy } \\
\text { sources }\end{array}$ & $\begin{array}{l}\text { Materials } \\
\text { efficiency } \\
\text { Responsible } \\
\text { sourcing } \\
\text { Whole life } \\
\text { analysis }\end{array}$ \\
\hline \multirow[b]{2}{*}{$\begin{array}{l}\text { S } \\
\text { oc } \\
\text { ie } \\
\text { ty }\end{array}$} & Population & Culture & Stakeholders & Services & Health & Vulnerability \\
\hline & $\begin{array}{l}\text { Vulnerable groups } \\
\text { Population change } \\
\text { Community } \\
\text { cohesion } \\
\text { Conflict sensitivity } \\
\text { Displacement }\end{array}$ & \begin{tabular}{|l|} 
Socio-cultural \\
identity \\
Cultural/religious \\
facilities \\
Heritage \& \\
archeology \\
Use of \\
environment \\
Intergenerational \\
gender practices \\
\end{tabular} & $\begin{array}{l}\text { Identification \& } \\
\text { analysis } \\
\text { Consultation \& } \\
\text { participation } \\
\text { Accountability \& } \\
\text { grievance } \\
\text { mechanisms }\end{array}$ & $\begin{array}{l}\text { Energy } \\
\text { Mobility \& } \\
\text { transport } \\
\text { Telecommunicati } \\
\text { ons } \\
\text { Education } \\
\text { Communal space }\end{array}$ & $\begin{array}{l}\text { Health } \\
\text { Sanitation } \\
\text { Solid } \\
\text { waste } \\
\text { Drainage } \\
\text { Healthcare } \\
\text { Shelter } \\
\text { Nutrition }\end{array}$ & $\begin{array}{l}\text { Climate change } \\
\text { Location \& env. } \\
\text { resources } \\
\text { Exposure \& } \\
\text { shelter } \\
\text { Institutions \& } \\
\text { social networks } \\
\text { Livelihood \& } \\
\text { finance }\end{array}$ \\
\hline \multirow[b]{2}{*}{$\begin{array}{l}\text { In } \\
\text { st } \\
\text { it } \\
\text { ut } \\
\text { io } \\
\text { n }\end{array}$} & Structures & Skills & Policies & Reporting & & \\
\hline & $\begin{array}{l}\text { National/local } \\
\text { government } \\
\text { effectiveness } \\
\text { Project } \\
\text { government } \\
\text { coordination } \\
\text { Corruption } \\
\text { Civil Society } \\
\text { Rule of law } \\
\end{array}$ & $\begin{array}{l}\text { Local government } \\
\text { Private sector } \\
\text { Civil society } \\
\text { involvement } \\
\text { Research \& } \\
\text { innovation }\end{array}$ & $\begin{array}{l}\text { Regulatory quality } \\
\text { Human rights } \\
\text { Health \& safety } \\
\text { Quality assurance } \\
\text { Intellectual } \\
\text { property rights }\end{array}$ & $\begin{array}{l}\text { Information } \\
\text { disclosure \& } \\
\text { reporting } \\
\text { Monitoring \& } \\
\text { evaluation } \\
\text { Media channels } \\
\text { Knowledge } \\
\text { exchange } \\
\text { Replication } \\
\end{array}$ & & \\
\hline \multirow[b]{2}{*}{$\begin{array}{c}\mathbf{E} \\
\text { co } \\
\mathbf{n} \\
\mathbf{o} \\
\mathbf{m} \\
\text { ic } \\
\mathbf{s}\end{array}$} & Viability & Macro & Livelihoods & Equity & & \\
\hline & $\begin{array}{l}\text { Value for money } \\
\text { Risk management } \\
\text { Carbon pricing } \\
\text { Operation \& } \\
\text { maintenance } \\
\text { National/regional } \\
\text { strategies } \\
\text { Appropriate } \\
\text { technologies }\end{array}$ & $\begin{array}{l}\text { Vitality \& } \\
\text { regeneration } \\
\text { Value } \\
\text { added/multiplier } \\
\text { effects } \\
\text { Ethical competition }\end{array}$ & $\begin{array}{l}\text { Local sourcing } \\
\text { Access to finance } \\
\text { Distortions to local } \\
\text { economy } \\
\text { Employment } \\
\text { creation } \\
\text { Labour standards } \\
\text { Training }\end{array}$ & $\begin{array}{l}\text { Equal } \\
\text { opportunities } \\
\text { Affordability of } \\
\text { services } \\
\text { Accrual of } \\
\text { benefits } \\
\text { Land tenure }\end{array}$ & & \\
\hline
\end{tabular}

Table 1: Indicators underpinning ASPIRE assessment (Source: Arup 2009) 


\section{Assessment Process}

The ASPIRE assessment (Table 2) comprises of four stages which include initiation of assessment, data collection and entry, review of outputs and reported. Those four stages are followed by the authors in order to ensure a robust assessment is carried out with due considerations to the local context, boundaries of assessment, policy framework, verification of evidence captured, review and clear reporting.
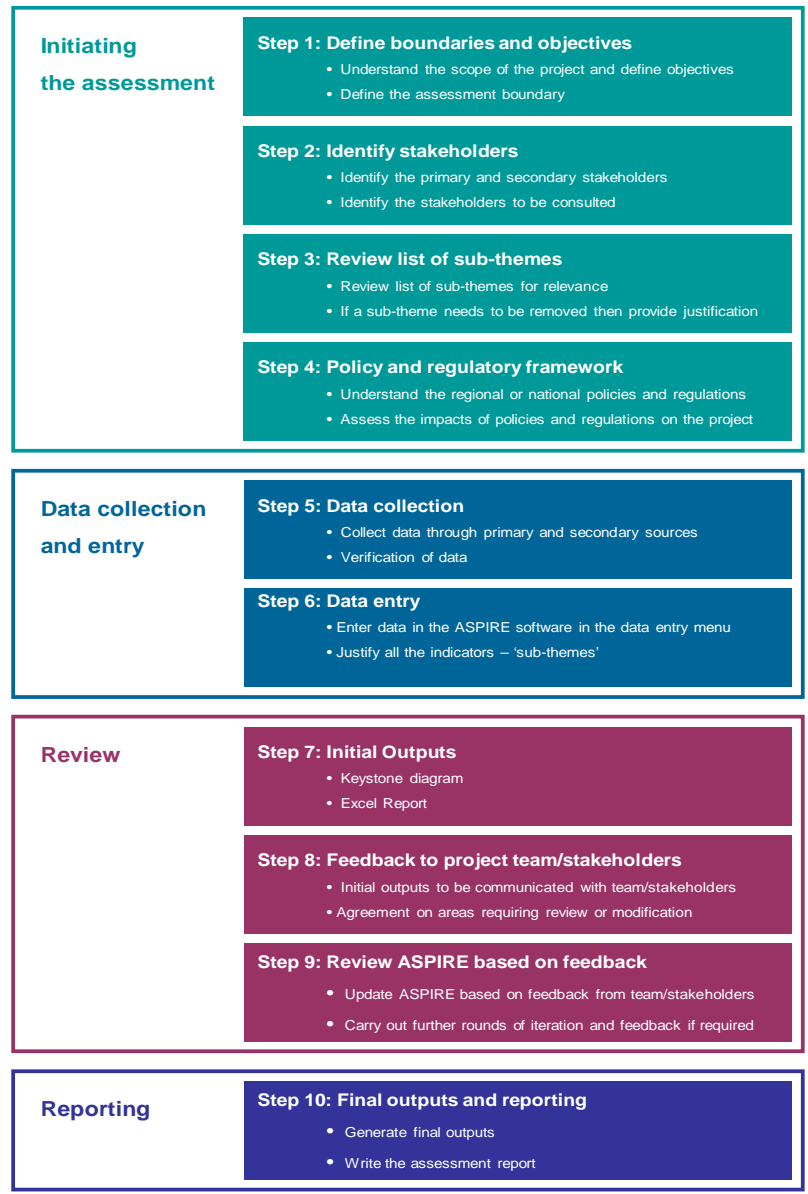

Table 2: ASPIRE assessment process (Source: Arup 2009)

\section{Initiating the Assessment}

The assessment covered Korail settlement in Bangladesh for most of the indicators. In some instances such as the institutional quadrant which is reliant on local and national governmental policy a broader boundary was adopted for the assessment. The assessment was carried out to assess the impact of UPPR project which commenced in 2008 and was ongoing during the assessment period of 2013.

UPPRP is funded by UKAID, UNDP, the Government of Bangladesh and local communities with USD 120 million earmarked in 2009 (UPPR, 2009). Implementing partners include the Local Government Engineering Department (LGED), Local Government Division, Ministry of Local Government, Rural Development and Cooperatives, Government of Bangladesh, UNDP and UNHABITAT. The authors 
managed to identify and interview two team members who had worked directly on the UPPR project.

The next part of the assessment was a review of list of indicators (sub-themes) to identify if there were indicators which were not relevant. The indicators for carbon pricing, ozone depleters, drylands and forests were deemed to be non-relevant and removed from the assessment process.

\section{Data Collection and Entry}

Evidence was captured initially from the project website of UPPR through their annual reports from 2009 to 2014. The UPPR project reports were used to understand the project background, institutional arrangements and phasing of the project. Further documentation and in particular specific details of the Korail site was obtained from project partners in May 2013 (UPPR(b)). In order to supplement the literature review five experts were identified through snowballing techniques and interviewed in-depth via skype in $2013^{1}$. Two experts had worked on the UPPR project in Dhaka as a town manager and the other as a specialist in poverty reduction. An expert from BRAC who had worked extensively on Korail for doctoral studies was interviewed to obtain insights into the local community and potential impact of the project. One expert who had worked in the field of housing in Bangladesh was interviewed to obtain independent feedback and one global expert on housing was approached to obtain a global perspective on the programme. The literature review provided evidence on the UPPR programme in Dhaka but evidence specific to Korail was provided by stakeholders directly involved in upgrading of Korail settlements. The ASPIRE assessment only used evidence captured in 2013 to carry out a one-off assessment of the project in Korail.

The ASPIRE toolkit comprises of 96 indicators out of which 92 were included in this assessment. Four indicators were reviewed and removed from the assessment as they were deemed to be non-relevant for the case study. The indicators of drylands and forests in the biodiversity theme were removed due to an absence of those features within the vicinity of the slum settlement. The theme of ozone depleters and carbon pricing were also removed as those indicators were not deemed to be relevant for a localised slum upgrading project.

Evidence from both the literature review and stakeholder interviews was used to score the 92 indicators (sub-themes). The scoring was based on a qualitative assessment of how well the indicator or theme had been addressed by the project as compared to the possible best or worst case scenario highlighted by the software (Figure 3). The scoring for the sub-themes are then represented by an average score in the ASPIRE output for twenty themes. Each scoring was accompanied by detailed justification which enabled the authors to acknowledge and clearly document primary and secondary data sources.

\footnotetext{
${ }^{1}$ Interview transcripts available from the authors on request
} 


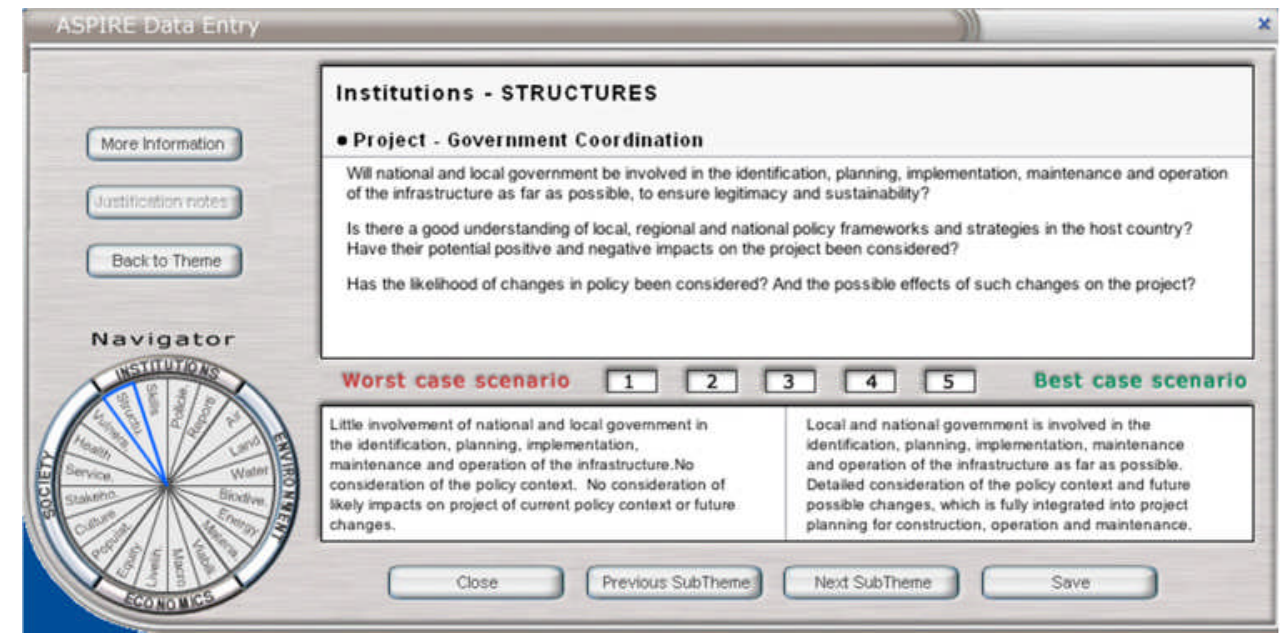

Figure 3 ASPIRE Data Entry Interface (Coordination Indicator within Institutions as illustration)

\section{Review and Reporting}

The scores within the software are aggregated for each of the main theme to produce a high level graphical output. The software also offers the opportunity to generate detailed reports for each sub themes in a Microsoft Excel. The visual graphical output also plots the best case output where the highest score is highlighted for each of the 20 themes and similarly the worst case output highlights the lowest score for all themes. This facilitates further scrutiny of strengths and weaknesses in lieu of the aggregate chart which indicates overall project performance.

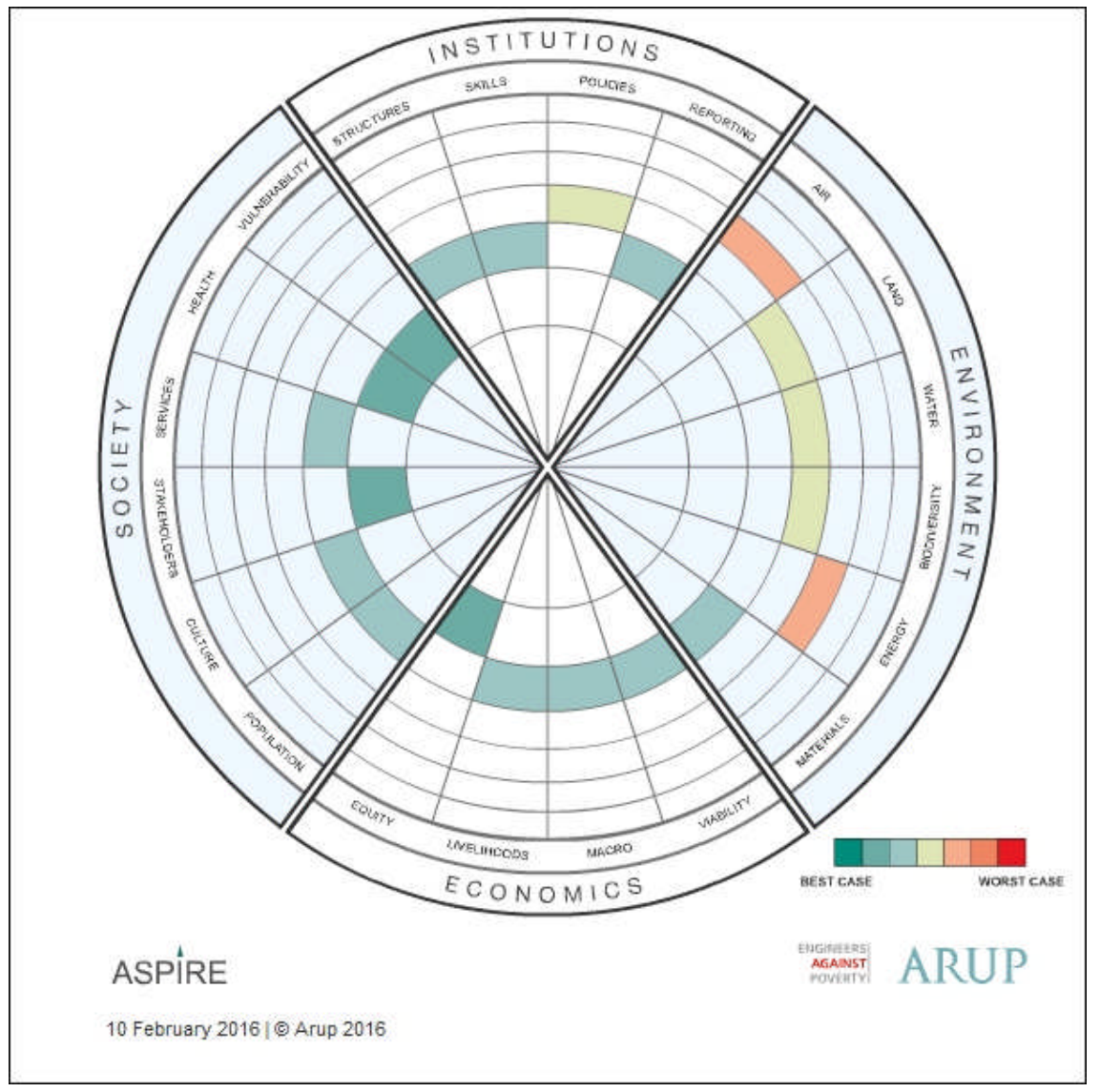

Figure 4 Initial normal-case (average) ASPIRE chart 
The first iteration of the ASPIRE assessment provided positive feedback for UPPR on all counts. The first iteration appeared to be quite optimistic (Figure 4). The main strengths were found in the social and economical themes whilst the weaknesses in the environmental and institutional ones. The outputs from the first iteration were shared with all respondents and one of the co-authors to obtain feedback. Based on stakeholder feedback on the output, the assessment was revised resulting in a more pragmatic output. Key changes included revised/reduced scores for the materials, institutional structures, provision of services, stakeholder engagement, population and equity themes. The extent of livelihood creation was deemed to be under estimated and hence this theme achieved a higher score in the final assessment. The next section of the paper highlights key findings from the assessment.

\section{Results and Discussion - Korail}

\section{ASPIRE Summary Report: Korail slum assessment}

The scoring displayed for a theme ranges from 1 through to 7 where 7 is the best score and 1 is the worst score.

\begin{tabular}{|l|l|l|}
\hline Quadrants & Themes & Scores \\
\hline Institutions & Structures & 4 \\
\cline { 2 - 3 } & Skills & 5 \\
\cline { 2 - 3 } & Policies & 4 \\
\cline { 2 - 3 } & Reporting & 5 \\
\hline \multirow{5}{*}{ Environment } & Air & 2 \\
\cline { 2 - 3 } & Land & 4 \\
\cline { 2 - 3 } & Water & 4 \\
\cline { 2 - 3 } & Biodiversity & 3 \\
\cline { 2 - 3 } & Energy & 3 \\
\cline { 2 - 3 } & Materials & 4 \\
\hline Society & Viability & 5 \\
\cline { 2 - 3 } & Macro & 5 \\
\cline { 2 - 3 } & Livelihoods & 6 \\
\cline { 2 - 3 } & Equity & 5 \\
\cline { 2 - 3 } & Population & 4 \\
\cline { 2 - 3 } & Culture & 5 \\
\cline { 2 - 3 } & Stakeholders & 4 \\
\cline { 2 - 3 } & Services & 5 \\
\cline { 2 - 3 } & Health & 5 \\
\cline { 2 - 3 } & Vulnerability & \\
\hline
\end{tabular}

Table 3: ASPIRE Summary scores for Korail

Table 3 presents average scores for the 20 ASPIRE themes which are indicated in the ASPIRE visual output (Figure 5). The normal case chart (Figure 5) presents an overall good performance of the project. The project appears to performs well against most of the ASPIRE themes. The normal case chart highlighted scope for improvement for energy, biodiversity and air quality management in the project. In order to evaluate the indicators in further detail the best and worst case charts were evaluated to specifically identify high and low scoring indicators. 


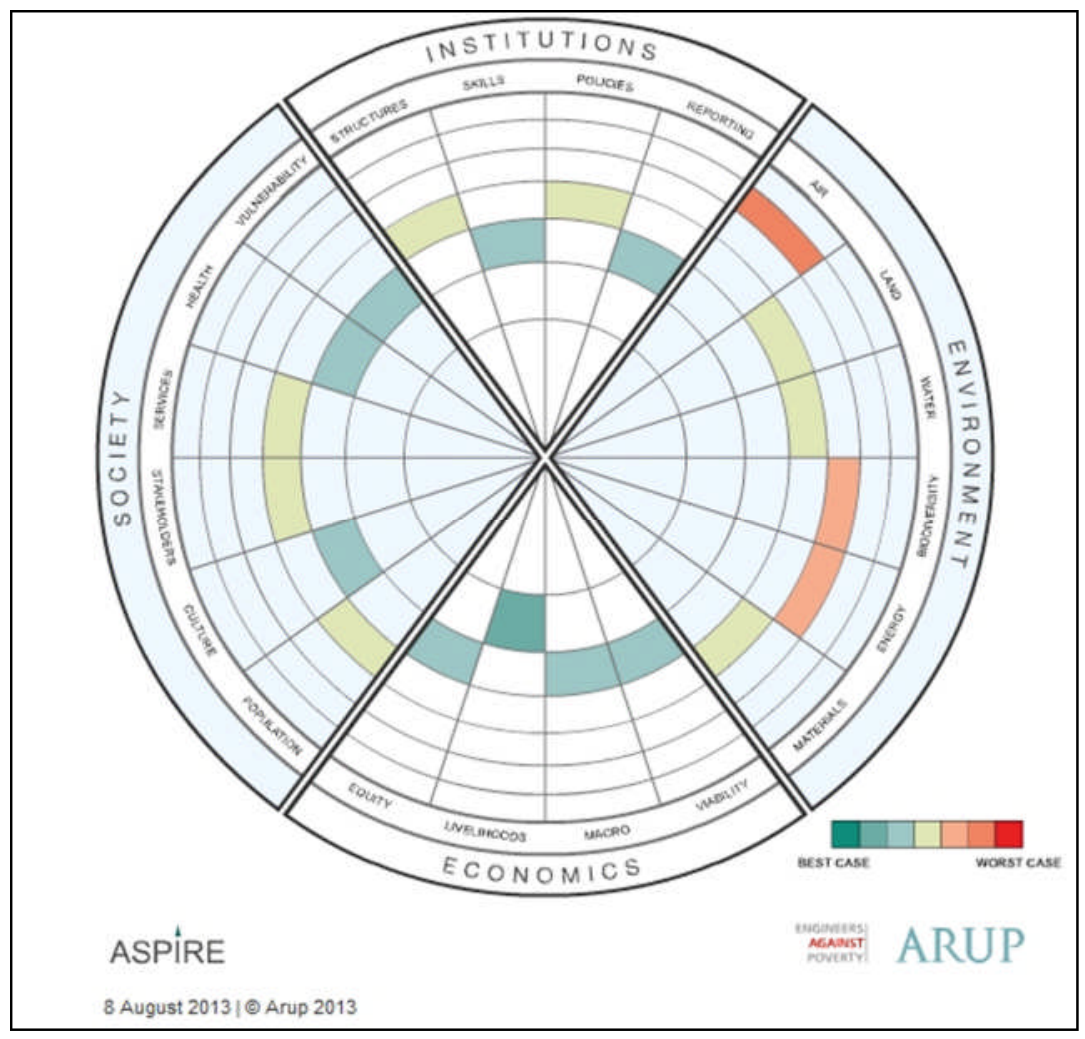

Figure 5 Normal-case (average) ASPIRE chart

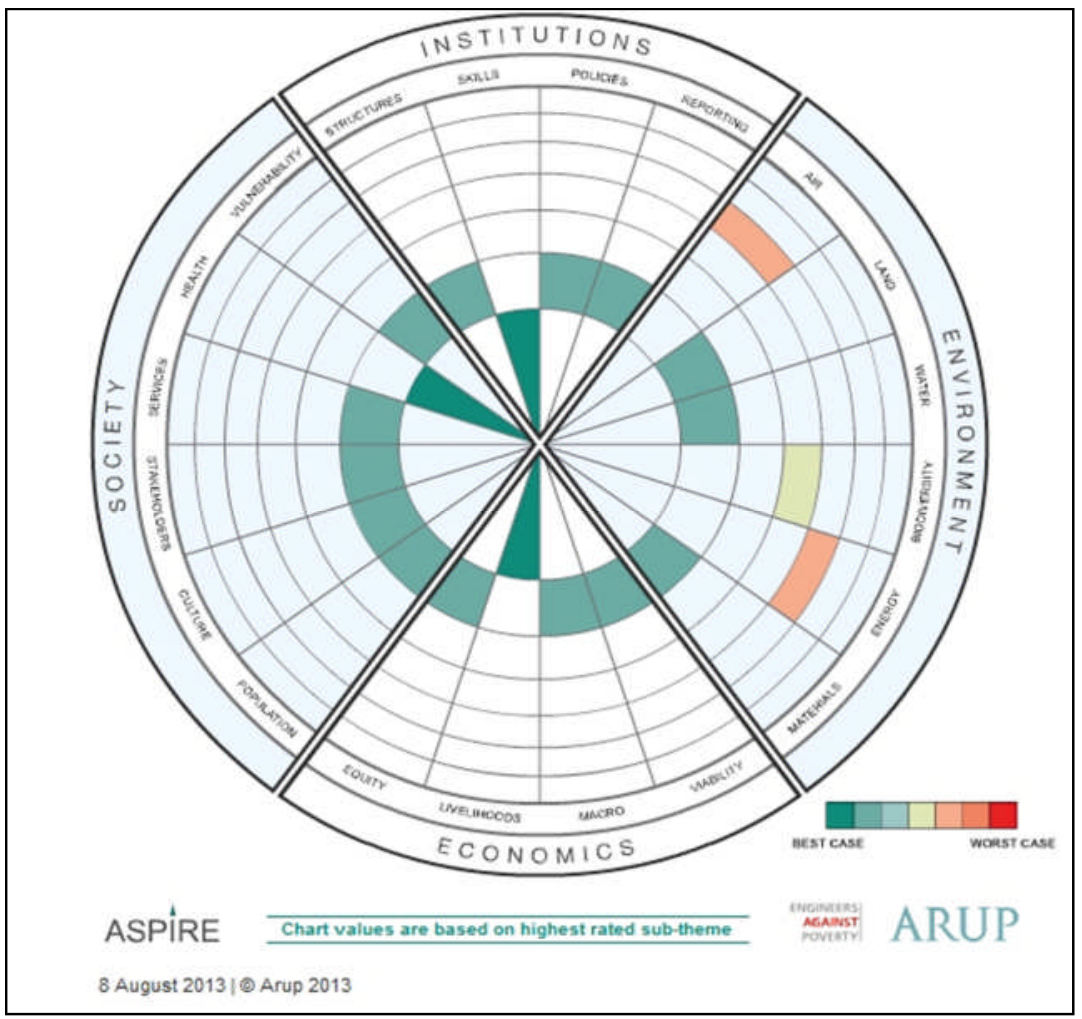

Figure 6 Best-case ASPIRE chart 


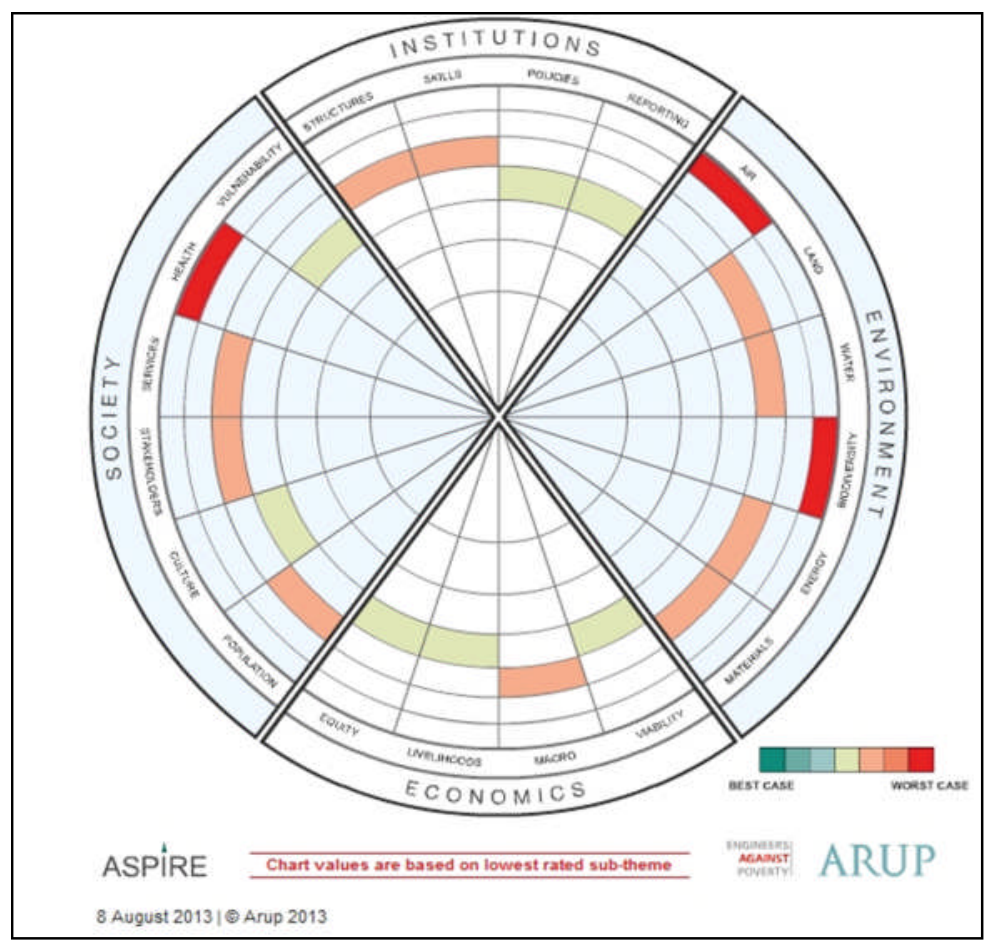

Figure 7 Worst-case ASPIRE chart

The best-case chart (Figure 6) highlights the areas where the project works best. It portrays the highest scoring sub-theme for each theme, which enabled the authors to break down and track the sub theme performance graphically. By observing the chart, the main strengths lie in:

- Skills theme specifically for the strong involvement of civil society

- Livelihood theme is strong for creating economic opportunities through SEF with training and apprenticeships schemes for local community members

- Health theme is strong through introduction of water and sanitation infrastructure which potentially improves health of residents.

The worst-case chart (Figure 7) represents the lowest scoring sub-theme for each theme and highlights the areas of weaknesses in the project. Predominantly weaknesses were identified in the environment quadrant of ASPIRE:

- Air quality was noted to be a challenge overall in Dhaka as the project did not improve pollution improvement measures for the city.

- Biodiversity was identified as a weak point in the assessment as cleaning up of and preservation of aquatic systems for Gulshan Lake was not included in the project scope.

\section{The institutional quadrant}

The project's fortes reside with the strong cooperation developed between the UPPRP team and the Local Government Engineering Department (LGED). The assessment highlights that the UPPRP structure has encouraged global funding and local government agencies to work together with a mission of improving quality of life for residents in slums. The work on access to basic services and access to livelihood opportunities can be extended to building climate change resilience for residents in Korail. 
Throughout UPPRP's success and achievements, a real dynamic has been established not only for the development of local authorities partnerships with local agencies or NGOs but more importantly, for the empowerment of the civil society. As argued by Rahman (2006) in his paper, NGO's support is fundamental for further emancipation of slum residents as with a genuine structure in place, slum inhabitants would then be able to fully deal with the constant population rise and resulting challenge of housing the population's poorest. In addition, pro-poor policy development brought understanding of fundamental values within the slum's environment, has encouraged Korail's residents to improve their quality of life through improved legitimacy.

Stakeholder interviews highlighted corruption as a barrier which potentially could undermine the project's benefits. By pushing for the expansion of pro-poor policies at local and national level, UPPRP team hopes to improve the regulatory framework at all levels. Another essential aim for the future of the project is to ensure accountability and transparency with Dhaka's partner local institutions which could potentially be achieved with the Bangladesh Urban Forum (BUF) that is now institutionalised with the support of the UPPR's implementing agencies such as UNDP, UN-HABITAT and UKAID. The BUF represents the strategy developed to strengthen the commitments of the Government of Bangladesh and the UN to address urban challenges in the nation.

\section{The environment quadrant}

It can be concluded that the overall environment of Korail was enhanced due to the knock-on effect that was created through improvements in both infrastructure and services. Healthier cooking systems, better footpaths and drainage, improved waste management, safe and legal gas supply and local material usage, have all contributed to improve Korail's environment. Core to the issue of the environment is the waste management process. Matter et al (2013) argue the benefits that would be engendered if the population was to utilise the informal recycling industry. The process coupled with waste generation would not only enhance the slum's environment as a whole but would also contribute to improve the slum population's health, physically and mentally.

Monitoring and regulating Korail's and the surrounding's pollution falls outside the UPPRP's work realm which is a weakness. Local authorities should consider a broader remit for environmental improvements to include surrounding water bodies and air quality in the city. This would result in an enhanced experience for slum dwellers where they would have access to clean water bodies and clean air.

\section{The economics quadrant}

The perfect intertwining of UPPR's financial contribution in the local economy also allowed trusting the upholding of the poorest peoples' revenue growth. Along with the installation of financial structures and services, the operation and maintenance fund in place ensures that the community has full ownership over the improved physical improvements and that they will manage to sustain it after the project's completion. The authors hope that post project completion, the community will keep its motivation and find incentives to further UPPRP's work.

Korail's population experienced qualitative gains with the regenerations of businesses in the slum as well as employment opportunities. As discussed by Smets (2006), 
incremental building and financing strategies tend to provide many more profits when utilised for small endeavours and in the case of Korail slum, the strategy of "thinking small" brought a wide array of benefits to the community. Women were engaged in apprenticeships and other livelihood initiatives which improved entrepreneurship within the community.

\section{The social quadrant}

The UPPRP aspired for community cohesion through the creation of community development committees that resulted in increased influence within the city council and hence, better acknowledgment of the slum and its residents. With help from external stakeholders, overall education within the slum was largely improved, whether for children with access to school or adults who were granted training and consequently, employment. Furthermore, with appropriate services in place and a resilient infrastructure, people are less vulnerable to external events and are better prepared to face the challenges of climate change. They are also less vulnerable to as they now have built local linkages and partnerships with important actors and have access to livelihood and financial opportunities. Frota (2008) highlights that economic development and social protection do not go hand in hand but breaking down the conceptual and administrative barriers between them would allow economic gains regarding the cost of services and could inherently help positive local development. This is presently reachable due to the increasing value and importance of the community's representatives.

One lasting issue seems to lie with threat of eviction although, more aware of their fundamental rights; people are now better prepared to fight for land rights. The fear of eviction appears to be a barrier for investment in housing. Attempts to evict residents have also resulted in loss of livelihood opportunities.

Whilst the community has much evolved socially, focus should be put on waste management and housing conditions, as these two remaining dilemmas would further enhance Korail's residents living conditions.

\section{Conclusion}

\section{UPPR Korail}

The unique community led approach implemented through infrastructure improvement community mobilisation, education and pro-poor policy development, was a true success.

Still, there are key areas within the project that could potentially be improved. One key lesson learnt through the ASPIRE assessment was the need to ensure security of land tenure. This can be achieved through initiatives such as improvements in community land purchase, leasing, land sharing and also by refining relationships between CDCs and common land owners. Improved communication is essential as information gathering and sharing with stakeholders would render possible similar infrastructure enhancement endeavours in other neighbourhoods. Securing a true partnership with 
Water Supply and Sewage Authority (WASA) would, for example, improve waste management and at the same time, allow for the creation of a recycling unit.

The project should also further the creation of sustainable horizontal linkages between the community and its stakeholders in order to guarantee the sustainability of the improved infrastructure and social developments. The project's leaders need to ensure a smooth handover to the community. Creating a multileveled participation of the public sector, the private sector and the citizens would facilitate service delivery throughout the country (Ahmed and Ali, 2006).

\section{Broader application of the work - Bangladesh and other countries}

Policy changes which improve infrastructure in developing countries have a positive impact on health, education, income and well-being (Calderón and Servén, 2004). Sustainable infrastructure can enable slum dwellers to shift from survival mode to aspirations for achieving a higher quality of life (Parikh, Chaturvedi and George, 2012a). As highlighted in annual reports (2010-2014) of UPPR the project has improved living conditions of thousands of residents through provision of basic services and improved access to livelihood opportunities.

With UPPRP's introduced dynamic and its many successes, it can be envisaged that there will be a positive knock-on effect to the authorities that may seek to reproduce some of its sustainable achievements. Environmental consideration needs to be strengthened because imposing regulations on land, water and air pollution will undeniably have a tremendous influence on the living condition of the entirety of Dhaka's population. UPPRP has the potential to address both environmental concerns and improve housing stock through targeted investment in infrastructure. The housing stock in Bangladesh needs improvements in urban finance structures coupled with environmental improvements supported by institutional structures to broker and effectively manage urban migration flows (Choguill, 1988). The provision of basic services can be used as a catalyst to generate investments in housing stock (Parikh et al, 2012).

\section{Application of ASPIRE Assessment}

For funding agencies such as UNDP and UKAID and implementing agencies such as local governments it is essential to monitor and evaluate interventions. Monitoring mechanims should highlight strengths and areas for improvement through a holistic assessment. The ASPIRE assessment for Korail highlighted the need for land tenure security and broader environmental inputs to ensure a longer term impact on residents. Poverty reduction should not be solely approached through infrastructure development but through an understanding of people's daily challenges and what is necessary in terms of enhanced quality of life. ASPIRE has proved to be relevant and extremely helpful in drawing out the institutional barriers and challenges in relation to improving slums settlements. The multi-dimensional assessment is simple to carry out and can be used by a non-expert on sustainable development to assess sustainability and poverty reduction goals. 
This paper uses secondary evidence and key stakeholder interviews to develop an ASPIRE assessment. Future work could include interviews with slum dwellers through participatory techniques to enhance the assessment. The further use of ASPIRE could potentially be to discuss trade-offs between environmental resources, economic enablers, institutional structures and social gaps through participatory workshops with slum dwellers and other stakeholders. A trip to the site would also include collection of data from health clinics, local government and mapping exercises with the local community. ASPIRE lends itself to an iterative process where the assessment can be updated on a regular basis to include new evidence. The paper describes an initial assessment which users would carry out before visiting a site in order to obtain a holistic view on project outcomes.

The annual reports developed by UPPR use indices of measurements such as multidimensional poverty index, women's empowerment index and settlement living conditions index which if measured at settlement level rather than city level can be integrated into the ASPIRE assessment. ASPIRE can be applied both at city and local scale so future work could also include comparison of city and slum level impact to see if localised factors have an impact on seemingly successful city level interventions. Maynard et al (2014) carried out a housing impact assessment using ASPIRE for four countries comparing lessons learnt across the four sites. There is scope to use ASPIRE for comparison of sites at same scale, compare across scales, ongoing monitoring through time series evaluation and as a stakeholder engagement tool where participants discuss environmental, institutional, economics and social aspects of the project.

Frameworks like ASPIRE can increase accountability and enable users to consider potential impact in a holistic manner at the outset of project intervention and then continue the learning through ongoing monitoring and evaluation.

\section{Acknowledgements}

This article is based on the case study of UPPR's work in the slum of Korail which is funded by UKAID and UNDP. The authors would like to thank the respondents who shared information about the project and spent time on skype interviews. We would also like to thank Victoria Cronin for reviewing the article and providing valuable feedback. The authors apply the ASPIRE toolkit which was developed by Arup and Engineers Against Poverty (EAP) in 2009. 


\section{References}

Ahmed, S. A., \& Ali, S. M. (2006). People as partners: Facilitating people's participation in public-private partnerships for solid waste management, Habitat International 30 (2006) 781-796.

Arup \& Engineers Against Poverty (EAP) (2009). A Sustainability Poverty and Infrastructure Routine for Evaluation (ASPIRE). Research and Development. Available from: http://www.engineersagainstpoverty.org/documentdownload.axd?documentre sourceid=29. Accessed June 2014.

Arup (2009). Background materials for training, developed by Arup International Development team to offer training to Arup offices.

Bangladeshi Bureau of Statistics (BBS) (2010). Report of the household income and expenditure survey 2010. Available from:

http://www.bbs.gov.bd/PageReportLists.aspx?PARENTKEY=66 . Accessed 20.06.14.

Bhattacharya, A., Romani, M. \& Stern, N. (2012). Infrastructure for development: meeting the challenge, Policy Paper, Centre for Climate Change Economics and Policy, Grantham Research Institute on Climate Change and the Environment in collaboration with Intergovernmental group of twenty four.

Calderón, C. \& Servén, L. (2004). The Effects of Infrastructure Development on Growth and Income Distribution, World Bank, Working Paper 3400: WPS3400.

Choguill, C. L. (1988). Problems in providing low-income urban housing in Bangladesh. Habitat International, 12(3), 29-39.

Choguill, C. L. (1996). Ten steps to sustainable infrastructure. Habitat International, 20(3), 389-404.

Cities Alliance, (2014). Climate migration drives slum growth in Dhaka. Available from: http://www.citiesalliance.org/node/420. Accessed December 2015.

Davis, Mike. (2007). Planet of Slums. 2nd ed. Brooklyn, NY: Verso.

Delwar Akbar, H. M., Minnery, J. R., Van Horen, B., \& Smith, P. (2007) Community water supply for the urban poor in developing countries: The case of Dhaka, Bangladesh, Habitat International 31, 24-35.

Dushtha Shasthya Kendra (DSK). (2012). Moving Backwards : Korail Slum Eviction, Dhaka, April 2012, A joint Shiree-DSK publication available

from: http://r4d.dfid.gov.uk/PDF/Outputs/EEP/Korail-Eviction-Report.pdf, Accessed December 2015.

Frota, L. (2008) Securing decent work and living conditions in low-income urban settlements by linking social protection and local development: A review of case studies, Habitat International 32, 203-222. 
Ghafur, S. (2000) Entitlement to Patronage: social construction of household claims on Slum Improvement Project, Bangladesh, Habitat International 24, 261-278.

International Centre for Diarrhoeal Disease Research, Bangladesh (ICDDRB). 2009. MANOSHI Working Paper 9 Available from:

http://www.icddrb.org/publications/cat_view/52-publications/10043-icddrbdocuments/10058-icddrb-reports-and-working-papers/10069-manoshi-workingpapers?start=10. Accessed June 2013

IRIN. (2009). BANGLADESH: air pollution chocking Dhaka. Available from: http://www.irinnews.org/report/83772/bangladesh-air-pollution-choking-dhaka. Accessed Juen 2014.

Jahan, S. \& McCleery, R. (2005) Making Infrastructure Work for the Poor: Synthesis Report of Four Country Studies Bangladesh, Senegal, Thailand and Zambia. United Nations Development Programme, New York.

Khan, S., \& Swapan, M. S. H. (2013). From blueprint master plans to democratic planning in South Asian cities: Pursuing good governance agenda against prevalent patron-client networks, Habitat International 38, 183-191.

Matter, A., Dietschi, M., \& Zurbrügg, C. (2013) Improving the informal recycling sector through segregation of waste in the household - The case of Dhaka Bangladesh, Habitat International 38, 150-156.

Maynard, V., Parikh, P., Simpson, D. \& Da Silva, J. (2014). Emerging Stronger? Assessing the outcomes of Habitat for Humanity's housing reconstruction programmes following the Indian Ocean tsunami. In Schilderman T. and Parker E., eds, Still Standing? Looking back at reconstruction and disaster risk reduction in housing. Rugby: Practical Action Publishing, pp. 21-37.

Mohit, A. (2012) Bastee Settlements of Dhaka City, Bangladesh: A Review of Policy Approaches and Challenges Ahead, Procedia - Social and Behavioral Sciences, Volume 36, 2012, Pages 611-622, http://dx.doi.org/10.1016/j.sbspro.2012.03.067.

Nielson, Catherine, Interview by Lynne Blundell. A confusion of tools raises issues... and a few hackles, The Fifth Estate. 2010. Available http://www.thefifthestate.com.au/archives/12503/. Accessed July 2014.

Rahman, M. M. (2002). Problems of the NGOs in housing the urban poor in Bangladesh, Habitat International 26, 433-451.

Parikh, P., Parikh, H., \& McRobie, A. (2012). The role of infrastructure in improving human settlements. Proceedings of the ICE-Urban Design and Planning, 166(2), 101118.

Parikh, P., Chaturvedi, S. \& George, G. (2012a). 'Empowering change: The effects of energy provision on individual aspirations in slum communities, Energy Policy, Vol. 50, pp. 477-485. 
Parikh, P., Fu, K., Parikh, H., McRobie, A., \& George, G. (2015). Infrastructure Provision, Gender, and Poverty in Indian Slums. World Development, 66, 468-486.

Smets, P. (2006). Small is beautiful, but big is often the practice: Housing microfinance in discussion, Habitat International 30, 595-613.

Subramanian, S.\&May, M. (2005) Korail Slum Eviction in Dhaka: Notes from the Field Available from http://www.globalhealthhub.org/2012/04/09/korail-slum-eviction-indhaka-notes-from-the-field/, Accessed December 2015.

Sustainable Energy for All (2013). Achieving Universal Energy Access, Available from : http://www.se4all.org/wp-content/uploads/2013/09/EnergyAccess.pdf, Accessed September 2015.

United Nations (UN). (2011). The Millennium Development Goals Report. Available from: http://www.un.org/millenniumgoals/11_MDG\%20Report_EN.pdf. Accessed June 2014.

UNHABITAT. (2014) Urban Partnerships for Poverty Reduction, Available from http://www.fukuoka.unhabitat.org/projects/bangladesh/detail02_en.html, Accessed December 2015.

Urban Partnerships for Poverty Reduction (UPPR). (2009). Urban Partnerhips for Poverty Reduction : Annual Progress Report, 2009. Available from: http://www.upprbd.org/projectrpts.aspx, Accessed December 2015.

Urban Partnerships for Poverty Reduction (UPPR). (2013). Urban Partnerhips for Poverty Reduction : Our Approach Available from: http://www.upprbd.org/ourapproach.aspx, Accessed December 2015.

Urban Partnerships for Poverty Reduction (UPPR). (2013b).UPPR Programme in Korail Slum, Gulshan, Dhaka, May 2013. Available from project partners.

Urban Partnerships for Poverty Reduction (UPPR). (2015). Urban Aprtnerships for Poverty Reduction : Annual Progress Report, 2015. Available from: http://www.upprbd.org/projectrpts.aspx, Accessed December 2015.

WORLD BANK. (2013). Example of Population Explosion: Dhaka Mega-City. Available from: http://web.worldbank.org/WBSITE/EXTERNAL/COUNTRIES/SOUTHASIAEXT/0,,c ontentMDK:21393869 pagePK:146736 piPK:146830 theSitePK:223547,00.html\#exa mple, Accessed December 2013.

World Health Organisation (WHO)-UN-Water (2014) UN-water global analysis and assessment of sanitation and drinking wter (GLASS) 2014 report, Investing in water and sanitation; increasing access, reducing inequalities, WHO. Available from: http://www.who.int/water_sanitation_health/publications/glaas_report_2014/en/ Accessed July 2015. 